Role of climate in the De-Urbanization of the Indus

\title{
Valley Civilization
}

${ }^{1}$ Gayatri Kathayat, ${ }^{1}$ Hai Cheng, ${ }^{2}$ Ashish Sinha, ${ }^{1} \mathrm{Li}$ Hanying.

${ }^{1}$ Institute of Global Environmental Change, Xi'an Jiaotong University, Xi'an, 710049.

${ }^{2}$ Department of Earth Science, California State University, Dominguez Hills, Carson, CA, 90747, USA

A global array of proxy records suggests that climatic conditions during the " $4.2 \mathrm{ka}$ event" may have been responsible for the downfall of several human civilizations globally. The link between the $4.2 \mathrm{ka}$ event and the deurbanization phase of the Indus Valley civilization, however, is particularly tenuous. While a high-resolution and absolutely dated speleothem oxygen isotope $\left(\delta^{18} \mathrm{O}\right)$ record of Indian summer monsoon (ISM) from Mawmluh cave, northeast India (Berkelhammer et al., 2012) show a major monsoon weakening, other speleothem $\delta^{18} \mathrm{O}$ records from north and northeast India suggest little to no change in ISM during the $4.2 \mathrm{ka}$ event. In this presentation, we will present new ISM $\delta^{18} \mathrm{O}$ data from Mawmluh Cave, Meghalaya, India to address this ambiguity. Our new data is at annual resolution with an average age uncertainty of \pm 13 years and fully encompasses the time interval before, during and after the $4.2 \mathrm{ka}$ event. We will first highlight the link between monsoon circulation, precipitation amount and precipitation oxygen isotope $\left(\delta^{18} \mathrm{Op}\right)$ at our study area using an isotope-enabled climate model (IsoGSM) and observational data. Furthermore, we will show that while our site is distally located from the core of the Indus settlement region, the $\delta^{18} \mathrm{Op}$ variability in this region is strongly sensitive to precipitation variability over the Indian subcontinent. In light of these findings, we will discuss the $4.2 \mathrm{ka}$ event in the larger context of monsoon variability over the past 5000 years.

\section{Reference:}

Berkelhammer, M., Sinha, A., Stott, L., Cheng, H., Pausata, F., Yoshimura, K.: An abrupt shift in the Indian monsoon 4000 years ago. Climates, landscapes, and civilizations, 75-88, 2012. 